\title{
The Effect of the Still Assurance on the Assurance Charge
}

\author{
I Nyoman Srimurti \\ \{nyomansrimurti@gmail.com\} \\ Universitas Warmadewa, Denpasar, Bali - Indonesia
}

\begin{abstract}
This study highlights the condition whether or not the debtor who transfers the guarantee that is still charged with mortgage rights can be prosecuted; it also deals with revealing the alternative solutions to avoid punishment. It makes use of empirical legal research design. The theory used to examine the issue is the legal certainty theory and scanning theory. The findings indicate that debtors who transfer control over the collateral that is imposed unilaterally could be convicted for fulfilling the provisions of embezzlement based on article 372 of the Criminal Code. The alternative way to solve this criminal act was a deliberation to reach an agreement. The conclusions of this study are that debtors who have broken promises and do not have good intentions to transfer control over collateral objects that have been burdened with mortgage rights can be convicted under the provisions of Article 372 of the Indonesian Criminal Code concerning embezzlement.
\end{abstract}

Keywords: Debtor; divert; fiduciary; mortgage rights

\section{Introduction}

To increase the rate of economic growth to realize the welfare of the community, the government encouraged various financial institutions to provide working capital to the community [1]. It is essential because banks as business actors that function as community financial intermediaries have strategic roles and functions, namely as development agents [2, $3,4]$. Without any interference from the bank to finance the economy of the community, the rate of economic growth of the people would be stagnant [5]. To provide working capital to the public, especially to bank customers, it is mandatory to apply prudential principles of prudence, honesty, transparency and accountability [6]. The legal principle of freedom of contract with customers must be taken into account to avoid juridical occurrence in the future. The collateral must be encumbered the mortgage rights to fulfil the provisions stipulated in Law of Republic of Indonesia number 4 of 1996 concerning Mortgage Rights.

The principle and good faith in conducting financial transactions between banks as creditors and customers as debtors must be implemented optimally [7]. Although the principles and good ethics have been implemented and included in the credit agreement, there are still debtors who do not keep their promises and do not act well [8] [9]. Most debtors of a bank transfer corresponding object has been burdened by mortgage rights as an indication of an unlawful act and a criminal act that meets the embezzlement element $[10,11]$. This paper intends to provide a review of cases where bank customers are defaulting due to transferring the ownership of collateral objects to third parties 
On the part of the bank in general if experiencing lousy, credit problems tend to take shortcuts to execute collateral. It is considered to be the easiest and cheapest to do because the collateral goods the customer has encumbered the mortgage. According to the Law concerning Mortgage Rights, through the auction office, the state of collateral can be executed, because on the mortgage rights certificate has been stated, "For Justice Based on the Supreme Godhead". The meaning is, the mortgage certificate has executive strength and does not require permission from the court to execute collateral.

Also in 2009, there was the idea of the bank involving law enforcement [12], in this case the police institution and the prosecutor's office to forcibly make bills to bank customers who were pledged. However, this idea received strong opposition from the community, so the idea of involving law enforcement in order to collect bad loans did not take place.

Indeed, bad credit has become a significant problem in the banking world [4]. However, if analyzed in more depth, the main problem is not only for customers. However, bad loans are also caused by the bank. In other words, if there is bad credit, the bank is also required to be responsible for jointly solving the problem. Bank errors can occur when analyzing collateral value, the credibility of prospective customers, and business prospects that are carried out by prospective customers. Failure to repay loans also occurs not only for customers but also for the national economy to have a considerable influence.

Other than that, natural disasters also affect the ability of customers to pay bank loans [6]. The most obvious example is that, due to the Mount Agung eruption disaster that occurred in Bali, many bank customers have lost the ability to pay credit in banks, causing nonperforming and non-performing loans.

This paper intends to analyze and answer problems related to the transfer of control of corresponding objects that have been burdened with mortgage rights. The problem is, what legal consequences can be accepted by bank customers who do not have good intentions because it diverts the guarantee object that has been burdened by mortgage rights.

This study uses empirical legal research. This type of research was chosen because the essence of the problem raised was the existence of a gap between the rules that apply to the reality in the field where the agreed credit agreement and fulfil the agreement in accordance with Article 1320 KUHPerdata and encumbered Mortgage Rights violated by the debtor by transferring control unilaterally to third parties. Because this paper examines a case that occurred at Subsidiary PT. Bank Pembangunan Daerah Bali of Klungkung. Then this is the basis of research using empirical law.

Based on research conducted, there appears to be indications of criminal violation, namely article 372 KUHP concerning embezzlement because all elements of the article have been fulfilled where the debtor precedes the intention, the existence of an act and a criminal violation committed intentionally, which has transferred the control of the object of guarantee to a third party. In this case, it appears to PT. The Regional Development Bank of Bali Klungkung Branch has difficulty in executing guarantees because the object of guarantee is in possession of third parties.

The purpose of this paper is to find out and understand what legal consequences can be imposed on bank customers who do not keep their promises by transferring the ownership of corresponding objects to third parties, even though it is known and realised that the corresponding object had been burdened with mortgage rights. Additionally, the benefits expected from this paper are, the community, especially bank customers, to increase their understanding and awareness, so that voluntarily without compulsion carry out their obligations to pay credit instalments in the bank and obey and implement what has been agreed in the credit agreement. It becomes very important because it will directly have a good 
impact on the economy of the community. The bank as an intermediary institution for public funds will get more trust from shareholders and savers in order to increase the amount of capital set by the government.

\section{Discussion}

In conducting lending and borrowing transactions between banks as creditors and the public as debtors, in general, the debtor hands over collateral. The forms of collateral are of various $[11,13]$ some objects move like vehicles, there are also immovable goods in the form of land and buildings. In practice, collateral items that become collateral are charged in the form of land title certificate documents. With the principle of fiduciary, the collateral goods are handed over to the debtor [14]. In this case, the debtor has the rights and obligations, namely, the right to use collateral goods, and must maintain, care for, and not transfer the collateral items for whatever reason to anyone.

In general, collateral is charged with mortgage rights as regulated in Law Number 4 of 1996 concerning Mortgage Rights. It is still related to mortgage rights the law that has closeness is Law Number 42 of 1999 concerning collateral fiduciary.

In practice, even though the credit agreement has been understood, approved and signed, but in the realm of fact, some of debtors do not act well by transferring collateral that has been charged with mortgage rights [15]. Transfers, in this case, can be in the form of granting, lending, and can also trade, which is all done by transferring the authority under the hands without involving an authorised official (notary/PPAT). Cases like this are prevalent in the community which harms the parties and damage the economy of the community.

In order to support the legal issue that transfer of guarantee rights burdened by mortgage rights is a criminal act, an understanding of the engagement between the debtor and creditor before the notary (PPAT) official, in which the essence of the engagement, in addition to regulating the rights and obligations of the parties, is also imaginatively confirmed there had been a transfer of rights to the land is proven by a clause that states:

a. If the debtor defaults, the creditor is given the authority to sell collateral objects through the state auction body (KPPLN).

b. Other instruments that provide further support for embezzlement legal issues are collateral institutions/processes to return the status of collateral ownership rights to debtors who do not default after credit has matured and paid in full because when the rights of land rights are transferred, ownership of the rights holders is imposed.

c. Another indicator that the transfer of collateral objects that have been charged with liability is a criminal offence is a violation of the clause as the head of the document, which is an eksetutorial title: "For the sake of justice based on the One God Almighty", where the rights holder may carry out legal actions without the permission of the debtor in default means here the transfer of land rights due to the imposition of mortgage rights.

Several legal provisions are violated by customers as bank debtors who transfer control over the charging of mortgage rights. The provisions in question can enter the criminal domain as stipulated in Article 372 the Criminal Code, and the provisions of illegal acts as stipulated in the provisions of Article 1365 of the Civil Code. The elements of criminal violations have been fulfilled, where the debtor precedes the intention, the act and the existence of a criminal offence where the guaranteed material is in the hands of the debtor occurs by not breaking the law. 
Meanwhile, to violate the law is if the actions taken by the bank's customers are proven to cause losses to other parties, in this case, the bank is a creditor. Indeed, it is not easy to prove unlawful actions and for this reason, several elements of unlawful actions can be formulated, namely, acting or not acting, violating propriety that lives in the community, the consequences can harm other parties [16] 7]. To understand illegal acts and criminal acts of fraud, below a case, will be submitted to be analysed to make it easier to understand the problem.

This study raised cases that occurred at PT. Bali Regional Development Bank Klungkung Branch. The legal issues and events are, there has been a unilateral transfer of control of collateral goods by the debtor to third parties unlawfully.

The problem lies below:

It began from the application of credit by a customer with a guarantee of a parcel of land with proof of ownership in the form of a land title certificate. After a technical review of the banking, the customer who submitted the creed was deemed eligible for the credit. Also, the collateral items that were being disbursed are also considered to be marketable and of sufficient economic value to repay the credit if there was a risk of default.

Finally, the loan was disbursed in a certain amount and within a specified period. After a customer domiciled as a debtor was given some working capital loans for a certain period, it turned out that the debtor did not carry out the obligations as stated in the credit agreement. In other words, the debtor did not make credit payments in the third month, and successively until the sixth month. The payment failure until the limit was due so that the loan on behalf of the debtor was classified in collectability to get special attention. Thus, procedurally and gradually the banks carried out various credit rescue efforts so that they did not become increasingly disobedient and increasingly difficult to pay.

a. The first effort carried out by the bank as a creditor is to provide coaching in a familial manner. Starting from going to his house, asking about the problem at hand. It is important to know and understand the fundamental problems faced by customers.

b. When the client's condition is known, a meeting is held to discuss what actions should be given later. In the meeting, it was decided to re-check the corresponding object if the unsuccessful billing effort was only then brought the lousy credit problem to the state auction hall. In other words, the bank wishes to carry out the execution of collateral that has been burdened by mortgage rights.

c. When the credit is problematic, or a default occurs, checking back to the field is known, it is known that a portion of the land owned by the owner is transferred to the third party, accompanied by a public facility on the land owned by the debtor which is used as collateral has been burdened with mortgage rights without unions of creditors as dependents.

Seeing this fact, the creditor still carries out guidance to the debtor and other efforts in the hope that the debtor will fulfil the obligation to pay the outstanding credit. Furthermore, credit rescue efforts are carried out through several stages by the established procedures, namely: that until the notification letter, the three debtors still do not heed the efforts made by the parties by PT. Bali Regional Development Bank Klungkung Branch, with indications that it still does not pay its debt so that the bank as a creditor decides to execute the collateral. At that time the debtor loan enters the collectability of the traffic jam. Approaching the execution, it turns out that there are some obstacles in the field, namely:

a. Before PT. The Regional Development Bank of Bali Branch of Klungkung wants to carry out the tender process request, it turns out the other party, in this case, the village institution represented by Kepala Desa where the assets of the guarantee object are stated that the history of the land was previously the village land or the land owned by the 
village. It means that the land belongs to a village institution, but at the time of the meeting of the villagers, the debtor hands over the land to build a public facility in the form of the village head's office without the creditor's or the bank's knowledge.

b. To settle bank credit as a creditor takes action not through litigation channels, but through non-litigation channels namely, first negotiating with the debtor and the other two parties who have controlled the land, namely the village institution.

c. PT. The Regional Development Bank of Bali Klungkung Branch is not only limited to negotiating with the relevant parties, but it is also accompanied by an application for auction assistance to the State Property and Auction Service Office (KPKNL). The case of executing the object of liability has been handled by the auction institution based on the execution request from PT. Bali Regional Development Bank Klungkung Branch which states that:

d. financing credit facilities on behalf of the debtor have been categorized as non-performing loans (non-performing loans); that in accordance with the provisions of the Financing Agreement as well as the general terms of the Financing Agreement, the Bank will endeavour to settle the customer's non-performing loan by auctioning collateral through a State Property and Auction Service Office with applicable legal provisions.

PT. The Regional Development Bank of Bali, Klungkung Branch, also asked the Appraisal Team, or the estimation team, to look directly into the field to assess the price of the land market. The aim is to determine the fair market value of collateral, where the fair market value consists of the lowest and highest value. This value will later be used as a basis for selling the collateral to parties participating in the auction. During this process, debtor loans enter the collectibility of bad debts.

Based on the description of the above problems, it is clear that there are indications of criminal acts in the form of embezzlement of collateral because the transfer of control is unilaterally the object of collateral to third parties [16]. Also, indications of an unlawful act have also appeared, because the consequences of customer actions that do not have good intentions cause losses to PT. Bali Regional Development Bank Klungkung Branch.

Thus the consequences of the transfer of land title, whose status is still burdened by mortgages by only making agreements under the hands of unilaterally transferring criminal acts, violating Article 372 of the Criminal Code concerning embezzlement, causes no legal certainty of the land ownership status for the recipient transfer of land rights, because the proof of ownership of land rights is still burdened with mortgage rights to creditors.

However, if the other party, in this case, the village institution as the recipient of the transfer of land rights has the desire to save the land that has been given so that the bank is not executed, the recipient of the transfer of land rights, namely the village institution, can pay off the debtor's debt. Thus the mortgage will wipe out the debt.

When reviewing this provision it seems relatively easy to solve, but the problem arises because the third party referred to in this case is a village institution which is not legally recognised as a legal subject so that it is not included as a supporter of rights and obligations.

\section{Conclusion}

Debtor liability that transfers control of collateral objects has been burdened with mortgage rights can be criminalised based on the embezzlement provisions stipulated in article 372 of the Criminal Code. However, this is not directly done by creditors or banks, but the 
process starts with an effort to deliberate to reach consensus. When this agreement is again neglected, the bank applies to the State Auction Office. Also, as a creditor, the bank may report customers who have no good intention to the authorities to be processed according to applicable law. In addition to banks being able to prosecute crimes based on embezzlement articles, debtors who do not have good intentions can also be sued on a local basis by committing an unlawful act. An indication of committing an unlawful act committed by the debtor is, because of the loss suffered by the bank as a creditor.

Acknowledgements. The author express the greatest gratitude to the organizing committee of the International Conference on Social Sciences (ICOSS) of Universitas Warmadewa for the great contribution that has been granted to the launching of this scientific script at EAI Publisher. Hopefully the ideas found in the paper can be additional to the theoretical and practical knowledge for many parties.

\section{References}

[1] Wilson, C and Tisdell, C.: Conflicts Over Natural Resources and the Environment: Economics and Security, Work. Pap. no. 86, pp. 1-33 (2003)

[2] Albanese, C, Brigo, D and Oertel, F.: Restructuring counterparty credit risk, Int. J. Theor. Appl. Financ. vol. 16 (2). pp. 1-29 (2013)

[3] Baldassarri, M, Paganetto, L and Phelps, E, S.: The Restructuring of Banks and Financial Systems in the Euro Area and the Financing of SMEs (2015)

[4] Albanese, C, Brigo, D and Oertel, F.: Restructuring counterparty credit risk, pp. 1-27 (2012)

[5] Zen, F.: Economic Diversification, The Case of Indonesia

[6] Apătăchioae, A.: The Performance, Banking Risks and their Regulation, Procedia Econ. Financ. vol. 20 (15). pp. 35-43 (2015)

[7] Portuese, A, Gough, O and Tanega, J.: The principle of legal certainty as a principle of economic efficiency, Eur. J. Law Econ. vol. 44 (1). pp. 131-156 (2017)

[8] Lizasoain, A, et al.: Penyelesaian Kredit Bermasalah Pada Pt. Bank Btpn Mur Tbk. Cabang Solo Naskah, vol. 119 (3). SOLO (2015)

[9] Meirah, A, D, E, Putri, D, Dwijaksara, S.: Penyelesaian Kredit Macet Ditinjau Dari, no. 37 (2017)

[10] Goldstein, H, W.: Fraud Enforcement and Recovery Act of 2009. Congress amends money laundering and criminal fraud statutes to expand their scope and penalties, J. Invest. Compliance, vol. 10 (3). pp. 37-40 (2009)

[11] Bakoush, M, Abouarab, R and Wolfe, S.: Disentangling the impact of securitization on bank profitability, Res. Int. Bus. Financ (2018)

[12] Ohyama, T and Amemiya, M.: Applying Crime Prediction Techniques to Japan: A Comparison Between Risk Terrain Modeling and Other Methods, Eur J Crim Policy Res (2018)

[13] Yusa, I, G.: Identification And Analysis Of The Rights Of Indigenous Peoples In The Study Of Constitutional Law, Const. Rev. vol. 2 (1) (2016)

[14] Tigar, M, E.: and Morals, vol. 11 (1). pp. 22-25 (2014)

[15] Morellec, E.: Asset liquidity, capital structure, and secured debt, J. financ. econ., vol. 61 (2) pp. 173-206 (2001)

[16] Pontell, H, N, Calavita, K and Tillman, R.: Corporate crime and criminal justice system capacity: Government response to financial institution fraud, Justice Q. vol. 11 (3). pp. 383-410 (1994) 